\title{
Research Climate and Institutional Support in Improving Performance of Scientific Publications at Private University in Indonesia
}

\author{
Ratna Komala Putri", Herman Sofyandi \\ Faculty of Business and Management, Widyatama University, Indonesia
}

Copyright $\mathrm{O} 2019$ by authors, all rights reserved. Authors agree that this article remains permanently open access under the terms of the Creative Commons Attribution License 4.0 International License

\begin{abstract}
Scientific publications on reputable international journals are very important outcomes of research. Universities that have a high number of scientific publications have high competitiveness in a country. The position of Indonesian publications in terms of numbers has outperformed Singapore and Thailand, but the level of citations to Indonesian journals remains low. So that this research must be carried out immediately which aims to produce a study of: the influence of the climate of research and institutional support in increasing the quantity and quality of scientific publications of private universities in Indonesia. The novelty in this study is that the number of scientific publications will increase if the Research Climate at the university is conducive and strong institutional support. The method used in this study uses quantitative research using Structural Equation Modeling analysis tools. The unit of analysis in this study is a private university in Indonesia. The targeted results are an increase in the quantity and quality of Indonesian scientific publications.
\end{abstract}

Keywords Research Climate, Institutional Support, Scientific Publication Performance, Higher Education

\section{Background of Research}

Scientific publications in reputable national and international journals play a role as a medium for self-actualization of academics and researchers in the development of international science. The measure of university success is judged by how well universities produce high-quality products that are recognized by society, both the scientific community and the general public.

The number of international publications has a role in increasing a country's self-esteem in the form of educational and scientific quality diplomacy. Countries that have good quality education and science and technology tend to have a high number of international publications. The same thing was stated by the Directorate General of Research and Development (2016) who realized that the number of international publications produced by Indonesian academics was still far behind compared to other countries, even with a number of ASEAN countries.

Indonesian scientific publications at the World level, based on data from The SCImago Journal \& Country Rank, Indonesia is ranked 53rd. In contrast to the data from Scopus according to the Kemristekdikti, the number of Indonesian scientific publications indexed by Scopus as of April 6, 2018 has surpassed Singapore and Thailand. It was noted that the number of Indonesian international scientific publications was 5,125, while Singapore 4,948 and Thailand 3,741, and Malaysia remained superior with 5,999. According to the Minister of Higher Education research and technology this achievement is a good thing even though it still leaves the problem of increasing publication but is not accompanied by an increase in citations from the article itself. Thus, quality must still be improved in order to improve performance in quantity and quality.

The trend of international publications is increasing because of the many supports the government has given. One of them is the regulation of the Minister of Research and Technology of Higher Education No 20/2017 concerning the Provision of Professional Lecturer Allowances and Professor Honor Allowances. There is also a regulation of the minister of research and technology of higher education No. 44/2015 that encourages masters and doctors to produce publications indexed globally. This is certainly the same effect that will also occur if the support is not only from the government side but the institution where the lecturers take shelter so that they are believed to have a far more significant impact. 


\section{Literature Review}

Human resource management is a grand theory that is used to study and analyze related problems in this study. Organizational behavior is used as a middle range theory. The levels of analysis are individuals, groups and organizations. Whereas apply theory is: Climate Research, Institutional Support and Scientific Publication Performance.

\subsection{Research Climate}

The climate from the Greek word is incline, which means that it is not only limited to physical things like temperature or pressure, but further has a psychological meaning that people who are members of an organization, live within the organization and interact to form a social system which in its development can't be separated from the influence of the environment both external environment and internal environment. This means that besides having to live with changes in the environment that are sometimes unpredictable, members of the organization also have to deal with the changes that exist within the organization. Climate is a dynamic system concept, the climate cannot be touched and seen, but the climate can be felt (Ahmed, Umrani, Qureshi \& Sarmad, 2018; Ali \& Haseeb, 2019; Haseeb, Abidin, Hye, \& Hartani, 2018; Haseeb, 2019; Suryanto, Haseeb, \& Hartani, 2018).

A very unique organization that makes each organization has a different psychological condition. Just as a university organization tends to create dynamic and attractive conditions for its academicians who differentiate from other universities. Organizational climate in universities is defined as a work atmosphere, attitudes, feelings, rules and interactions that form a characteristic, personality and beliefs regarding rules and policies that can influence the behavior of lecturers in carrying out tasks in a university environment (Alfawair and Al Tobi, 2017; Mayan and Nor, 2017; Yulisutiany, 2018; Ha and Tran, 2018; Garaeva and Ahmetzyanov, 2018; Altunkaya and Ates, 2018; Ratna, 2018; Allam, 2018; Andriansyah et al., 2018; Tayebi et al., 2019; Pourkhani et al., 2019). Based on the Law of the Republic of Indonesia Number 14 of 2005 concerning Teachers and Lecturers of Article 1 paragraph 2, the main task of a lecturer is the Tri Dharma of Higher Education, one of which is Research. On this basis, the university must create conducive atmosphere for lecturers in conducting research.

Research in general can be interpreted as a scientific way to obtain data that has certain purposes and uses. Scientific method meant that the research activities were based on scientific characteristics, rational, empirical, and systematic to achieve certain goals. It is said rationally that the research was carried out in ways that made sense. The empirical means that the methods carried out can be observed by the human senses, whereas systematic means the process carried out using logical methods. Data collection and analysis process uses scientific methods, both quantitatively and qualitatively. According to Kerlinger (1986) research is interpreted as a process of discovery that has systematic, controlled, empirical characteristics, and is based on theory and hypothesis. While Emzir (2007: 3) says that research is an attempt to find, develop, and test the truth of knowledge, which is done by scientific methods. Suryana (2010) said that research activities must pay attention to several values such as emotional neutrality, universalism, openness, independence, and its strength lies in the argument.

Based on several notions of climate and research, constructs were obtained regarding research climate as the work atmosphere, attitudes, and interactions of lecturers in finding, developing and testing the truth in a systematic, empirical, controlled, open and independent manner within the university (Tolulope, 2017; Rahman and Zhang, 2017).

\subsection{Institutional Support}

In organization, social interaction can occur in the context of individuals with their organizations. Before reviewing institutional support, it is first explained about the concept of organizational support. Organizational support can be defined as members' perceptions of the extent to which organizations provide support to employees and the extent to which the organization is prepared to provide assistance when needed. Ivancevich (2014: 44) holds that organizational support has a number of support and feelings received by colleagues, superiors, and departments that assist in the success of tasks and work. Erdogan and Enders (2007) define organizational support as an individual's belief that organizations care and provide input by providing assistance and support. "According to Mathis \& Jackson (2001: 84) organizational support is the support received from the organization in the form of training, equipment, expectations and productive work teams, while Ratna (2018) focuses on organizational support for a university, namely the extent to which universities provide support, assistance when needed, appreciation of contributions, care for social-emotional needs, well-being, relationships and feelings of mutual assistance among lecturers and leader.

However, this study generalizes more towards higher education institutions, so that the construct of institutional support is obtained by the support received by lecturers in the form of training, resources, caring for the needs of lecturers, giving sufficient time to complete tasks.

\subsection{Performance of Scientific Publications}

The success of an organization is influenced by employee performance. Basically, performance is what 
employees do or don't do. Lussier (2008: 8) argues that performance is the extent to which expectations or goals have been met. Different opinions expressed by Raymond J. Stone (2008: 36) that performance is related to certain achievements or achievements that are shown in completing work. John Bernardin (2010: 222) defines performance as a record of results resulting from the functions of certain work activities or activities during a specific time period.

In higher education, the measure of the success of institutional performance is very dependent on the performance of lecturers in carrying out their duties and responsibilities. Because based on the Law of the Republic of Indonesia Number 14 of 2005 concerning Teachers and Lecturers of Article 1 paragraph 2, Lecturers are professional educators and scientists with the main task of transforming, developing, and disseminating science, technology and art through education, research, and service to society. One of the performance of Higher Education is to produce high quality products that are recognized by the public, both the scientific community and the general public. The product is one of the scientific works published in national and international scientific journals. Scientific publication is a mandatory requirement that must be fulfilled by lecturers as academic office holders. as stated in article 46 (2) of Law No. 12 of 2012 and Article 44 (5) Minister of Research, Technology and Higher Education Regulation Number 44 of 2015 that research results that are not confidential, do not disturb and or do not endanger the public interest or national must be disseminated by means of a seminar, publication, patenting, and/or other means that can be used to convey research results to the public. Published means that the results of research are published in accredited scientific journals and/or books that have been published by universities or other publishers and have ISBNs. Based on several opinions and studies of books, journals and laws, the performance of scientific publications, namely the quantity and quality of results are in realizing the goals, objectives, vision and mission of the university in the field of scientific publications.

\section{Research Methods}

The research design used in this study is quantitative research. The purpose of this study is to develop a conceptual model of the performance of lecturers' scientific publications into novelty in the form of model findings through hypothesis testing. Hypothesis testing is done by using quantitative research design that is by making research questions using an ordinal scale with the answer criteria 5 to be asked to private university lecturers in Indonesia. The answers from each respondent were then coded, tabulated and then processed using SEM according to the research objectives and respondent size.

The population in the study is a private university in
Indonesia, based on the search results obtained from the dictation page, it is known that the number of universities in Indonesia is 432 . This study is more focused on private university lecturers on Java, because $59 \%$ of Indonesian private universities are on Java. Determining a representative sample size of a large number of populations, structural equation models are used which at least take 200 observations. The variables observed were: Research climate, institutional support, performance of scientific publications.

\section{Result and Discussion}

Hypothesis testing is done to find out whether the research climate has an effect on the performance of scientific publications, along with an explanation of the results of partial hypothesis testing:

Table 1. Partial Testing

\begin{tabular}{|l|c|c|c|}
\hline Hypothesys & $\gamma$ & R square & t.test \\
\hline $\begin{array}{l}\text { Research climate } \rightarrow \text { Performance of } \\
\text { Scientific Publications }\end{array}$ & 0.31 & 0.26 & 2,41 \\
\hline $\begin{array}{l}\text { Institutional support } \rightarrow \text { Performance of } \\
\text { Scientific Publications }\end{array}$ & 0.27 & 0.22 & 2,06 \\
\hline
\end{tabular}

$* \alpha=0.05(\mathrm{t}$ table $=1.96)$

These results indicate that the research climate plays an important role in improving the performance of university scientific publications. So that the research carried out must have high innovation. Availability of research resources must be considered, such as citation journals, textbooks, and other supporting literature. Collaboration with universities in the country and abroad in the form of research cooperation or holding conference cooperation, with a high level of research innovation, adequate resources and collaborative research and conferences, the performance of university scientific publications will increase.

Based on the testing of the hypothesis of the influence of institutional support on the performance of the university, it can be seen that the amount of influence is $22 \%$. This shows that the increase in the performance of university scientific publications is also influenced by the increase in institutional support. It is means that if the university continues to conduct scientific article writing training and scientific publication training. Providing support for research funding and scientific publications, as well as providing opportunities for lecturers to attend seminars or scientific conferences. So, Scientific Publication of private universities in Indonesia will increase in terms of quantity, quality and timeliness of scientific publications of private universities in Indonesia can increase.

Table 2. Simultaneous Testing

\begin{tabular}{|l|c|c|}
\hline Hypothesys & R square & F test \\
\hline $\begin{array}{l}\text { Research climate and Institutional } \\
\text { Support } \rightarrow \text { Performance of Scientific } \\
\text { Publications }\end{array}$ & 0.48 & 34,21 \\
\hline
\end{tabular}


These results indicate that the climate of research and institutional support can improve the performance of university scientific publications by $48 \%$. Thus, with high research innovations, research resources are available in full, increasing collaboration with universities in the country and abroad, training in writing scientific articles and scientific publications, providing funding for conferences and scientific publications and always providing opportunities to lecturers to take part in scientific seminars and conferences, the quantity, quality, and time of achievement to be ranked first in ASEAN.

\section{Conclusions}

The research findings show that the climate of research consisting of research innovation, increased research resources and collaboration with universities at home and abroad can improve the quantity and quality of university scientific publications. The same goes for institutional support in the form of increasing the training of scientific article writing and scientific publications, funding support for lecturer research and providing lecturers with opportunities to attend scientific seminars and conferences capable of increasing the quantity and quality of university scientific publications. So that if the conducive research climate and the institution support it, Indonesian scientific publications are able to occupy the main position in ASEAN both in terms of quantity and quality.

\section{REFERENCE}

[1] Bernardin, Jhon. 2010. Human Resource Management. An Experiential Approach. International Edition. Published by Mc. Graw-Hill Companies, Inc., 1221. Avenue of the Americas, New York.

[2] Emzir. (2007). Research methodology. Jakarta: Raja Grafindo Persada.

[3] Erdogan, B., Enders, J. (2007). Support from the top: Supervisors' Perceived Organizational Supportas Amoderator of Leader-Member Exchange To Satisfaction and Performance Relationship. Journal of Applied Psychology, 92(2), 321-330. http://dx.doi.org/10.1037/002 1-9010.92.2.321.

[4] Ivancevich, Konopaske, Mattenson., 2014., Organizational behavior \& Management., Tenth Edition., Publish by McGraw-Hill., New York., America.

[5] Kerlinger, F.N., 1986, Principles of Behavioral Research, Gajah Mada University Press.

[6] Lussier, Robbert., 2008., Human Reltions in Organizations. Aplications and Skill Biilding. Seventh Edition., published by MCGraw-Hill/Irwin, a business unit of The MCGraw-Hill Companies, Inc., 1221 Avenue of the Americas, New York.
[7] Mathis, R \& Jackson, J. 2011. Human Resource Management. Terjemahan Diana Angelica. Jakarta: Penerbit Salemba Empat.

[8] Putri, Ratna, (2018). The Academic Climate And Organizational Support Influence On Performance Of Lecturers Scientific Publications., International Journal of Engineering \& Technology, Vol. 7 (3) (2018.

[9] Raymond A. Noe. 2010 Employee Training and Development. Fifth Edition. Exlusive rights by McGraw-Hill Educational. Nort American Version.

[10] Raymond J. Stone. 2008. Human Resource Management, sixth edition. Published by John Wiley \& Sons Australia, Ltd.

[11] Republic of Indonesia Law Number 14 of 2005 concerning Teachers and Lecturers

[12] Law No. 12 of 2012 concerning Higher Education

[13] Garaeva, A. K., \& Ahmetzyanov, I. G. (2018). Awareness of Historical Background as One of the Factors of Better Language Acquisition. International Journal of English Language and Literature Studies, 7(1), 15-21.

[14] Tolulope, A. (2017). Demographic Variables as Factors Influencing Accessibility and Utilisation of Library Software by Undergraduates in Two Private Universities in Nigeria. Journal of Education and e-Learning Research, 4(3), 92-99.

[15] Altunkaya, H., \& Ates, A. (2018). Sources of Reading Anxiety among the Learners of Turkish as a Foreign Language. Asian Journal of Education and Training, 4(3), 161-169.

[16] Rahman, K. A., \& Zhang, D. (2017). Material Culture and Environmental Woes: Devotion to Fast Fashion. Humanities and Social Sciences Letters, 5(3), 54-63.

[17] Alfawair, A. M., \& Al Tobi, A. S. (2017). Counseling Needs for Students with Special Needs at the University. American Journal of Education and Learning, 2(1), 65-74.

[18] Mayan, S. N. A., \& Nor, R. M. (2017). Prospects and challenges of ecotourism sector and poverty eradication in Sabah: The case of orangutans and Mabul Island. Global Journal of Social Sciences Studies, 3(1), 1-12.

[19] Yulisutiany, I. (2018). Study of Education Competency and Effect on Learning Process of BCCT Method on Educational Group of Education Age (PAUD) in Sukasari Bandung. International Journal of Educational Technology and Learning, 3(2), 69-77.

[20] Ha, T. P. T., \& Tran, M. D. (2018). Review of Impacts of Leadership Competence of Project Managers on Construction Project Success. International Journal of Emerging Trends in Social Sciences, 4(1), 15-25.

[21] Allam, Z. (2018). Students' perception of quality in higher education: An empirical investigation. Management Science Letters, 8(5), 437-444.

[22] Andriansyah, A., Taufiqurokhman, T., \& Wekke, I. (2019). Responsiveness of public policy and its impact on education management: An empirical assessment from Indonesia. Management Science Letters, 9(3), 413-424. 
[23] Tayebi, S., Manesh, S., Khalili, M \& Sadi-Nezhad, S. (2019). The role of information systems in communication through social media.International Journal of Data and Network Science, 3(3), 245-268.

[24] Pourkhani, A., Abdipour, K., Baher, B \& Moslehpour, M. (2019). The impact of social media in business growth and performance: A scientometrics analysis.International Journal of Data and Network Science, 3(3), 223-244.

[25] Ahmed, U., Umrani, W. A., Qureshi, M. A., \& Samad, A. (2018). Examining the links between teachers support, academic efficacy, academic resilience, and student engagement in Bahrain. INTERNATIONAL JOURNAL OF ADVANCED AND APPLIED SCIENCES, 5(9), $39-46$.

[26] Ali, A., \& Haseeb, M. (2019). Radio frequency identification (RFID) technology as a strategic tool towards higher performance of supply chain operations in textile and apparel industry of Malaysia. Uncertain Supply Chain Management, 7(2), 215-226.

[27] Haseeb, M., Abidin, I. S. Z., Hye, Q. M. A., \& Hartani, N. H. (2018). The Impact of Renewable Energy on Economic Well-Being of Malaysia: Fresh Evidence from Auto Regressive Distributed Lag Bound Testing Approach. International Journal of Energy Economics and Policy, 9(1), 269-275.

[28] Suryanto, T., Haseeb, M., \& Hartani, N. H. (2018). The Correlates of Developing Green Supply Chain Management Practices: Firms Level Analysis in Malaysia. International Journal of Supply Chain Management, 7(5), 316. 